\title{
Identifikasi Perubahan Pola Curah Hujan dan Periode Masa Tanam Padi di lahan Kering untuk Adaptasi Perubahan Iklim (Studi Kasus Kabupaten Bone, Sulawesi SELATAN)
}

\author{
IDENTIFICATION OF Changes in RaINFall Pattern AND LENGth of \\ Growing Period in Rainfed Rice Field for Climate Change \\ adaptation (Case Study in Bone District, South SUlaWESI)
}

\section{Yeli Sarvina}

Balai Penelitian Agroklimat dan Hidrologi, Kementerian Pertanian

Jl. Tentara Pelajar No. 1 A Cimanggu Bogor 1611

E-mail: ysvina@yahoo.com/yelisarvina@pertanian.go.id

\begin{tabular}{|c|c|}
\hline ARTICLE INFO & Abstract \\
\hline $\begin{array}{l}\text { Article history } \\
\text { Received date: } \\
\text { 2018-04-10 } \\
\text { Received in revised form date: } \\
\text { 2019-06-12 } \\
\text { Accepted date: } \\
\text { 2019-06-12 } \\
\text { Available online date: } \\
\text { November } 2019\end{array}$ & $\begin{array}{l}\text { Identification of climate change impacts on spatial and temporal rainfall } \\
\text { pattern and length of growing period are very important for climate } \\
\text { change adaptation strategy. Rainfed is an agro-cosystem most sensitive } \\
\text { to changes in rainfall patterns. Bone Regency is a center of agriculture in } \\
\text { South Sulawesi and has considerable rainfed potentials. This study aims to } \\
\text { identify changes of rainfall patterns and length of growing period (LGP) } \\
\text { for paddy and upland rice in Bone Regency. Data of three rian stations } \\
\text { with a 55-year period were used and Oldeman methods was applied to } \\
\text { determine rainfall pattern and LGP. Data was separated in two period, } \\
\text { period } 1 \text { (1961-1990) and period II (1991-2016). The pattern of changes } \\
\text { were identified by comparing rainfall patterns in LGP I and II. This analysis } \\
\text { was grouped by wet year, normal year and dry year with criteria developed } \\
\text { by BMKG. The results of the analysis showed that the rainfall pattern and } \\
\text { LGP had changed of which pattern of change varies between regions. The } \\
\text { LGP of paddy in Macope were three months shorter in all years, while for } \\
\text { upland rice were two months shorter in wet year, and I month in normal } \\
\text { year. In Katumpit, the LGP of paddy fields were } 2 \text { months shorter comparing } \\
\text { to the wet year and l month shorter in normal and dry year for upland rice. } \\
\text { LGP for paddy in Cellu was lengthened } 1 \text { month in wet year and shortened } \\
2 \text { months in dry year for upland rice. } \\
\text { Keywords: Climate change, Rainfall, Length of growing periode, Rainfed, } \\
\text { Upland rice }\end{array}$ \\
\hline
\end{tabular}

Kata kunci:

Perubahan Iklim

Curah Hujan

Periode masa tanam

Lahan kering

Air

\begin{abstract}
Abstrak
Identifikasi dampak perubahan iklim terhadap pola curah hujan dan panjang periode masa tanam padi baik secara spasial maupun temporal sangat penting bagi pertanian terkait upaya adaptasi. Lahan kering merupakan agroekosistem yang paling sensitif terhadap perubahan pola curah hujan. Kabupaten Bone merupakan sentra-pertanian di Sulawesi Selatan dan memiliki potensi lahan kering yang cukup luas. Penelitian ini bertujuan untuk mengidentifikasi perubahan pola curah hujan dan periode masa tanam padi baik padi sawah maupun padi gogo di kabupaten Bone. Data tiga stasiun hujan dengan periode 55 tahun digunakan untuk mengindetifikasi perubahan pola curah hujan dan periode masa tanam padi. Data dianalisis dalam dua periode, yaitu periode I (1961-1990) dan periode II (1991-2016) dengan menggunakan metode Oldeman. Pola perubahan diidentifikasi dengan membandingkan pola curah hujan dan periode masa tanam periode I dan II. Analisis dikelompokkan berdasarkan Tahun Basah, Normal, dan Kering menggunakan kriteria BMKG. Hasil analisis menunjukkan terjadi perubahan pola curah hujan dan berdampak terhadap periode masa tanam padi dengan pola perubahan berbeda antar-wilayah kajian. Periode masa tanam padi sawah di Macope berkurang hingga tiga bulan pada semua tahun sedangkan periode masa tanam padi gogo berkurang dua bulan pada Tahun Basah dan satu bulan pada Tahun Normal. Periode musim tanam padi sawah di Katumpi berkurang dua bulan pada Tahun Basah sedangkan periode masa tanam padi gogo berkurang satu bulan pada Tahun Normal dan Kering. Terjadi peningkatan periode tanam padi sawah satu bulan pada Tahun Basah di wilayah Cellu, sedangkan periode masa tanam padi gogo berkurang dua bulan pada Tahun Kering.
\end{abstract}




\section{PENDAHULUAN}

Kabupaten Bone merupakan sentrapertanian pangan di Sulawesi Selatan yang memiliki lahan sawah $110.760 \mathrm{Ha}$ dengan luas sawah irigasi $43.508 \mathrm{Ha}$ dan sawah non-irigasi 67.252 $\mathrm{Ha}$, luas tegalan $69.022 \mathrm{Ha}$, ladang $5.470 \mathrm{Ha}$, dan belum diusahakan 22.206 Ha (BPS 2017). Sebagian besar lahan kering di kabupaten Bone digunakan untuk budidaya palawija dengan komoditas utama jagung dan baru dimanfaatkan sekitar 24,09\% (Biba 2012). Potensi pemanfaatan lahan kering di kabupaten ini masih sangat besar. Herniwati dan Syafruddin (2009) menyebutkan bahwa untuk meningkatkan produktivitas pertanian di Sulawesi Selatan, potensi sumber daya iklim dan lahan harus dioptimalkan.

Permasalahan utama budidaya pertanian di lahan kering adalah ketersediaan air dan produktivitasnya yang sangat rendah. Hayashi et al. (2018) menyebutkan secara umum rendahnya produksi di lahan kering disebabkan oleh iklim yang semakin tidak menentu, jumlah curah hujan yang terbatas, dan nutrisi tanah. Hal ini sejalan dengan penelitian yang dilakukan oleh Biba (2012), menyebutkan bahwa masalah utama yang dihadapi petani lahan kering di kabupaten Bone terutama untuk budidaya jagung adalah pola perilaku iklim yang semakin tidak menentu dan curah hujan yang tinggi pada saat panen. Taufik et.al (2015) juga melaporkan salah satu penyebab rendahnya produktivitas jagung lahan kering di Sulawesi Selatan adalah adanya stagnasi curah hujan pada saat pertumbuhan tanaman.

Beberapa hasil penelitian di atas menunjukkan bahwa iklim terutama curah hujan menjadi faktor yang sangat penting dalam usaha tani di lahan kering. Informasi tentang karakteristik curah hujan sangat penting bagi pertumbuhan dan perkembangan tanaman tidak hanya jumlahnya tetapi juga pada distribusi curah hujan (Guan et al. 2015). Perubahan iklim yang telah menjadi isu global secara nyata telah memberikan dampak negatif yang sangat signifikan pada sektor pertanian, sehingga menambah kompleks permasalahan usaha tani di lahan kering. Latha et.al (2012) menyebutkan bahwa petani di lahan kering adalah kelompok yang paling rentan terdampak perubahan iklim.

Dampak perubahan iklim yang sangat penting bagi pertanian adalah perubahan pola curah hujan dan perubahan periode masa taman (Runtunuwu dan Syahbuddin 2007; Ruminta dan Nurmala 2016; Laimeheriwa 2014; Susilokarti et al. 2017; Setiawan 2012). Dampak perubahan pola curah hujan ini berbeda antar-wilayah sehingga perlu dilakukan kajian lebih spesifik dan dalam skala yang lebih detail.

Prakiraan iklim terbukti mampu mengurangi risiko kegagalan usaha tani di lahan kering (Hayashi et al. 2018; Meza et al. 2008; Roudier et al. 2016). Prakiraan iklim sangat penting untuk mengetahui awal musim dan distribusi curah hujan ke depan sehingga diperoleh periode masa tanam optimal yang pada akhirnya petani dapat menyesuaikan masa tanam sesuai kondisi iklim. Surmaini dan Syahbuddin (2016) menyebutkan bahwa penyesuaian waktu tanam adalah langkah adaptasi pertanian yang paling murah. Pemahaman tentang pola dan perubahan iklim sangat penting untuk menyusun prakiraan iklim, di samping itu perubahan pola iklim dalam jangka waktu yang panjang sangat penting untuk menyusun langkah adaptasi perubahan iklim.

Linderholm (2006) menyebutkan tiga pendekatan yang digunakan untuk menentukan periode masa tanam dan perubahannya, yaitu berdasarkan data fenologi tanaman, citra satelit, dan data klimatologi. Pada penelitian ini pendekatan yang digunakan adalah menggunakan data 
klimatologi terutama curah hujan selama 55 tahun. Periode masa tanam juga bisa didekati dengan beberapa pendekatan. Thornthwaite (1948) dan Thornthwaite and Mather (1955) mengembangkan hubungan curah hujan dan evapotranspirasi untuk menentukan masa tanam. Metode ini sering juga disebut metode book keeping. Pada metode ini dihitung surplus dan defisit kadar air tanah berdasarkan curah hujan sebagai input dan evapotranspirasi sebagai output sehingga metode ini juga dikenal dengan sistem neraca air. Metode lain yang sering digunakan adalah metode Schmidt dan Ferguson (1951), yaitu membandingkan rata-rata bulan basah dan kering. Nilai rasio ini dikenal dengan faktor Q. Metode lain yang sangat sering diaplikasikan di Indonesia adalah metode Oldeman (1975), pendekatan ini lebih menekankan aplikasi pada bidang pertanian sehingga sering juga disebut sebagai klasifikasi iklim pertanian. Metode Oldeman hanya menggunakan data curah hujan bulanan dengan pendekatan kebutuhan air minimal tanaman padi, yaitu sekitar $200 \mathrm{~mm}$. Pada setiap bulan ditentukan periode Bulan Basah (BB), yaitu bulan dengan curah hujan lebih besar dari 200 mm dan Bulan Kering (BK) apabila curah hujan kurang dari $100 \mathrm{~mm}$. Panjang masa tanam ditentukan berdasarkan jumlah BB. Beberapa kajian penentuan pola curah hujan dan periode masa tanam dengan menggunakan data klimatologi disajikan pada Tabel 1.

Penelitian ini bertujuan untuk mengindentifikasi perubahan pola curah hujan dan dampaknya terhadap panjangnya masa tanam padi di kabupaten Bone, Sulawesi Selatan dengan menggunakan data klimatologi. Informasi perubahan pola curah hujan dan periode masa tanam ini dapat digunakan sebagai dasar kebijakan dalam menyusun langkah adaptasi perubahan iklim di wilayah ini.

\section{METODE}

Data yang digunakan dalam penelitian ini adalah data curah hujan selama 55 tahun, yaitu data tahun 1961-2016. Data ini diperoleh dari Dinas Pekerjaan Umum dan Sumber Daya Air Sulawesi Selatan. Sebelum digunakan untuk analisis, dilakukan pengecekan kualitas data (quality control) data seperti pengecekan data kosong dan outlier serta uji homogenitas data. Prosedur pengecekan kualitas data mengikuti metode yang dikembangkan oleh Durre et al. (2010). Sebaran stasiun dan potensi lahan ditunjukkan pada Tabel 2. Ketiga stasiun tersebar di tiga kecamatan pada kabupaten Bone. 
Tabel 1. Penelitian-penelitian yang berkaitan dengan pola curah hujan dan periode masa tanam

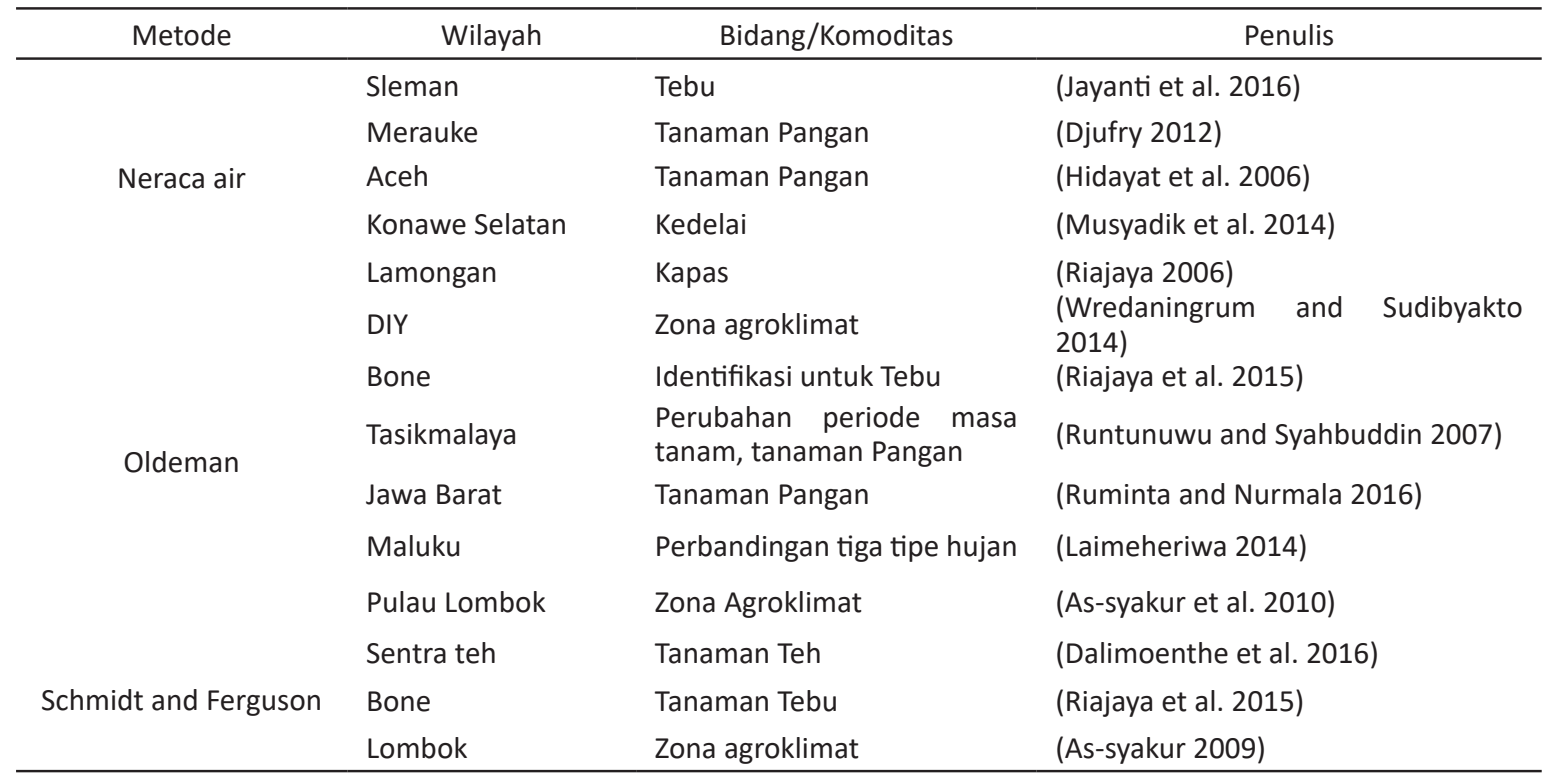

Tabel 2. Pos hujan yang digunakan dalam penelitian

\begin{tabular}{|c|c|c|c|c|c|}
\hline No. & $\begin{array}{c}\text { Nama } \\
\text { Pos }\end{array}$ & $\begin{array}{l}\text { Keca- } \\
\text { matan }\end{array}$ & $\begin{array}{c}\text { Luas } \\
\text { sawah } \\
\text { irigasi }\end{array}$ & $\begin{array}{c}\text { Sawah } \\
\text { non } \\
\text { irigasi }\end{array}$ & $\begin{array}{c}\text { Ladang } \\
\text { dan } \\
\text { tegalan }\end{array}$ \\
\hline 1 & Cellu & $\begin{array}{c}\text { Tanete } \\
\text { Riattang }\end{array}$ & 1002 & 208 & 419 \\
\hline 2 & $\begin{array}{c}\text { Katumpi } \\
\text { / BP.I }\end{array}$ & Cina & 2253 & 1419 & 1322 \\
\hline 3 & Maccope & $\begin{array}{c}\text { Awang } \\
\text { Pone }\end{array}$ & 2130 & 3492 & 1980 \\
\hline
\end{tabular}

Data pengamatan dibagi dalam dua periode, yaitu periode I (1961-1990) dan periode II (1991-2016). Rata-rata curah hujan pada periode I disebut curah hujan normal periode I dan demikian juga dengan periode II. Pada setiap tahun pengamatan ditentukan sifat hujan yang dibagi dalam tiga kategori, yaitu Tahun Basah (TB), Tahun Normal (TN), dan Tahun Kering (TK). Kriteria yang digunakan dalam klasifikasi ini adalah kriteria yang dikembangkan oleh BMKG (2017) yang disajikan pada Tabel 3.

Tabel 3. Kriteria klasfikasi sifat hujan (BMKG 2017)

\begin{tabular}{ccc}
\hline No & Sifat hujan & Kriteria \\
\hline 1 & Tahun Basah & $>115 \%$ curah hujan normal \\
2 & Tahun Normal & $85-115 \%$ curah hujan normal \\
3 & Tahun Kering & $<85 \%$ curah hujan normal \\
\hline
\end{tabular}

Panjang masa tanam padi sawah ditentukan dengan metode Oldeman. Metode ini menggunakan curah hujan bulanan sebagai dasar klasifikasi. Bulan Basah (BB) adalah bulan dengan curah hujan lebih besar dari $200 \mathrm{~mm}$, Bulan kering (BK) apabila curah hujan kurang dari $100 \mathrm{~mm}$ dan Bulan Normal (BN) bila curah hujan bulanan antara 100-200 mm. Berdasarkan jumlah $\mathrm{BB}, \mathrm{BK}$ dan $\mathrm{BN}$, (Oldeman 1975)telah menyusun pola hujan dan periode masa tanam seperti pada Tabel 4. Pada budidaya padi lahan kering atau padi gogo, masa tanam ditetapkan dengan nilai $\mathrm{CH}$ minimal $100 \mathrm{~mm}$ (Puslitbangtan 2006).

Tabel 4. Panjang masa tanam berdasarkan metode Oldeman (1975)

\begin{tabular}{ccccc}
\hline No. & $\begin{array}{c}\text { Pola } \\
\text { Hujan }\end{array}$ & $\begin{array}{c}\text { Jumlah BB } \\
\text { (Bulan) }\end{array}$ & $\begin{array}{c}\text { Jumlah BK } \\
\text { (Bulan) }\end{array}$ & $\begin{array}{c}\text { Periode } \\
\text { masa } \\
\text { tanam } \\
\text { (Bulan) }\end{array}$ \\
\hline 1. & A & $>9$ & $<2$ & $10-12$ \\
2. & B1 & $7-9$ & $<2$ & $11-12$ \\
3. & B2 & $7-9$ & $2-4$ & $9-10$ \\
4. & B3 & $7-8$ & $4-5$ & $7-8$ \\
5. & C1 & $5-6$ & $<2$ & $11-12$ \\
6. & C2 & $5-6$ & $2-4$ & $9-10$
\end{tabular}




\begin{tabular}{ccccc} 
7. & C3 & $5-6$ & $5-6$ & $6-8$ \\
8. & D1 & $3-4$ & $<2$ & $11-12$ \\
9. & D2 & $3-4$ & $2-4$ & $9-10$ \\
10. & D3 & $3-4$ & $5-6$ & $6-8$ \\
11. & D4 & $3-4$ & $>6$ & $3-5$ \\
12. & E1 & $<3$ & $<2$ & $11-12$ \\
13. & E2 & $<3$ & $2-4$ & $9-10$ \\
14. & E3 & $<3$ & $5-6$ & $6-8$ \\
15. & E4 & $<3$ & $>6$ & $<6$ \\
\hline
\end{tabular}

Perubahan pola curah hujan diperoleh dengan cara membandingkan pola hujan dan panjang musim tanam pada TB, TN, dan TK pada periode I dan II. Secara umum metode penelitian digambarkan pada diagram alir penelitian yang disajikan pada Gambar 1.

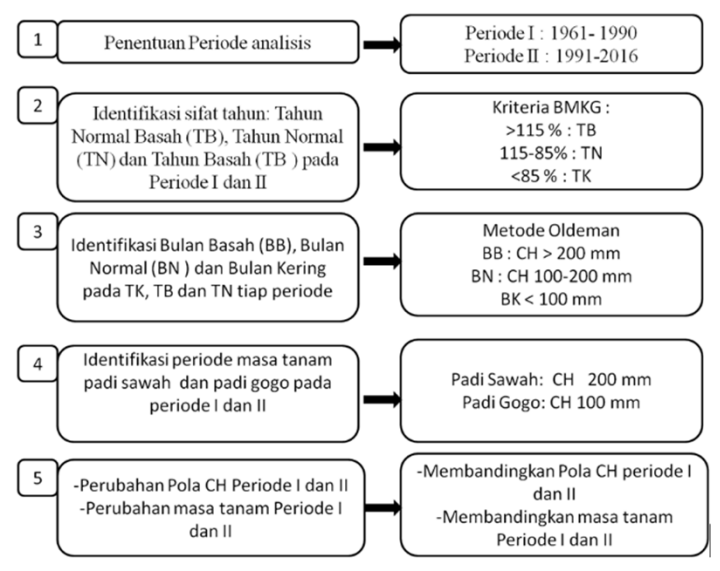

Gambar 1. Diagram alir penelitian

\section{HASIL DAN PEMBAHASAN Sifat Hujan}

Identifikasi sifat hujan pada dua periode analisis untuk tiga wilayah di kabupaten Bone disajikan pada Tabel 5. Curah hujan tahunan di wilayah Macope sedikit meningkat sedangkan di Katumpi dan Cellu menunjukkan tren penurunan. Dari curah hujan tahunan ini terlihat bahwa ketiga stasiun ini memiliki rata-rata curah hujan tahunan $>2.000 \mathrm{~mm}$ sehingga masuk dalam kategori lahan kering beriklim basah (Mulyani 2016). Lahan seperti ini pada umumnya memiliki kemasaman yang tinggi $(\mathrm{PH}<5)$, serta mengalami pencucian hara yang insentif sehingga tanah miskin hara.

Pada Tabel 5 juga ditampilkan
fase El-Nino southern oscillations
(ENSO) yang diunduh melalui situs
http://www.cpc.ncep.noaa.gov/products/. Hasil penelitian (Hendon 2003) dan (Aldrian and Dwi Susanto 2003) melaporkan bahwa ENSO merupakan salah saktu faktor interannual variabilitas, yaitu faktor yang memengaruhi keberagaman iklim antar-tahun di Indonesia

Kekuatan fase ENSO yang disajikan pada Tabel 5 hanya kekuatan sedang (moderate) hingga sangat kuat yaitu El-Nino kuat/Strong El-Nino (SE), El-Nino Sangat Kuat/Very Strong El-Nino (VSE), El-Nino Moderat/Moderate El-Nino (ME), La-Nina Sangat Kuat/Very Strong La-Nina (VSL), La-Nina Kuat/Strong La-Nina (SL), La-Nina Moderat/Moderate La-Nina (ML). Jika dilihat dari fase ENSO terlihat bahwa terjadi perubahan pengaruh ENSO di ketiga wilayah ini pada kedua periode analisis. Tahun El-Nino ditandai dengan kotak merah dan tahun La-Nina ditandai dengan kotak hijau. El-Nino menyebabkan terjadinya penurunan curah hujan di sebagian besar wilayah Indonesia sedangkan La-Nina menyebabkan peningkatan curah hujan. Pada periode I pengaruh El-Nino dan La-Nina dalam dengan kekuatan moderat sampai sangat kuat tidak berpola tetapi pada periode II terlihat pola yang semakin jelas dimana pada El-Nino Moderat hingga sangat kuat sifat tahunnya adalah TK dan pada tahun La-Nina sifat tahunnya pada umumnya adalah TB. Ini menunjukkan bahwa pengaruh sirkulasi global seperti ENSO semakin kuat di wilayah ini. Perubahan iklim disinyalir menyebabkan peningkatan inten- 
sitas dan frekwensi El-Nino dan La-Nina (Timmermann et al. 2006).

\section{Pola Hujan}

Distribusi curah hujan bulanan dengan metode (Oldeman 1975) digunakan untuk melihat pola hujan. Pola hujan disajikan pada dua periode analisis pada TN, TK, dan TB. Ringkasan perubahan Jumlah BB, BK, dan BN disajikan pada Tabel 6.

Dalam kurun 55 tahun pola hujan di kabupaten Bone telah berubah, di Macope terlihat bahwa jumlah BB menurun pada $\mathrm{TB}, \mathrm{TN}$, dan TK sedangkan jumlah BK meningkat pada TB dan TN. Pola hujan di ketiga sifat hujan berubah dan menunjukkan tren penurunan curah hujan, ini mengidentifikasikan wilayah ini semakin kering. Perubahan pola curah hujan di Katumpi agak berbeda dengan di Macope, di wilayah ini BB menurun di TB tetapi tetap di TN dan TK, sementara BK tetap pada TB tetapi meningkat pada TN dan TK. Pola hujan di Katumpi ini, pada TB dan TN cenderung lebih kering sedangkan pada TK tetap. Pola perubahan curah hujan di Cellu juga mengalami perubahan dimana jumlah BB meningkat pada TB, tetap pada TN dan TK. Jumlah BK tetap pada TB dan TN tetapi meningkat pada TK.

Tabel 5. Sifat Hujan Tahunan Periode 1961-2016

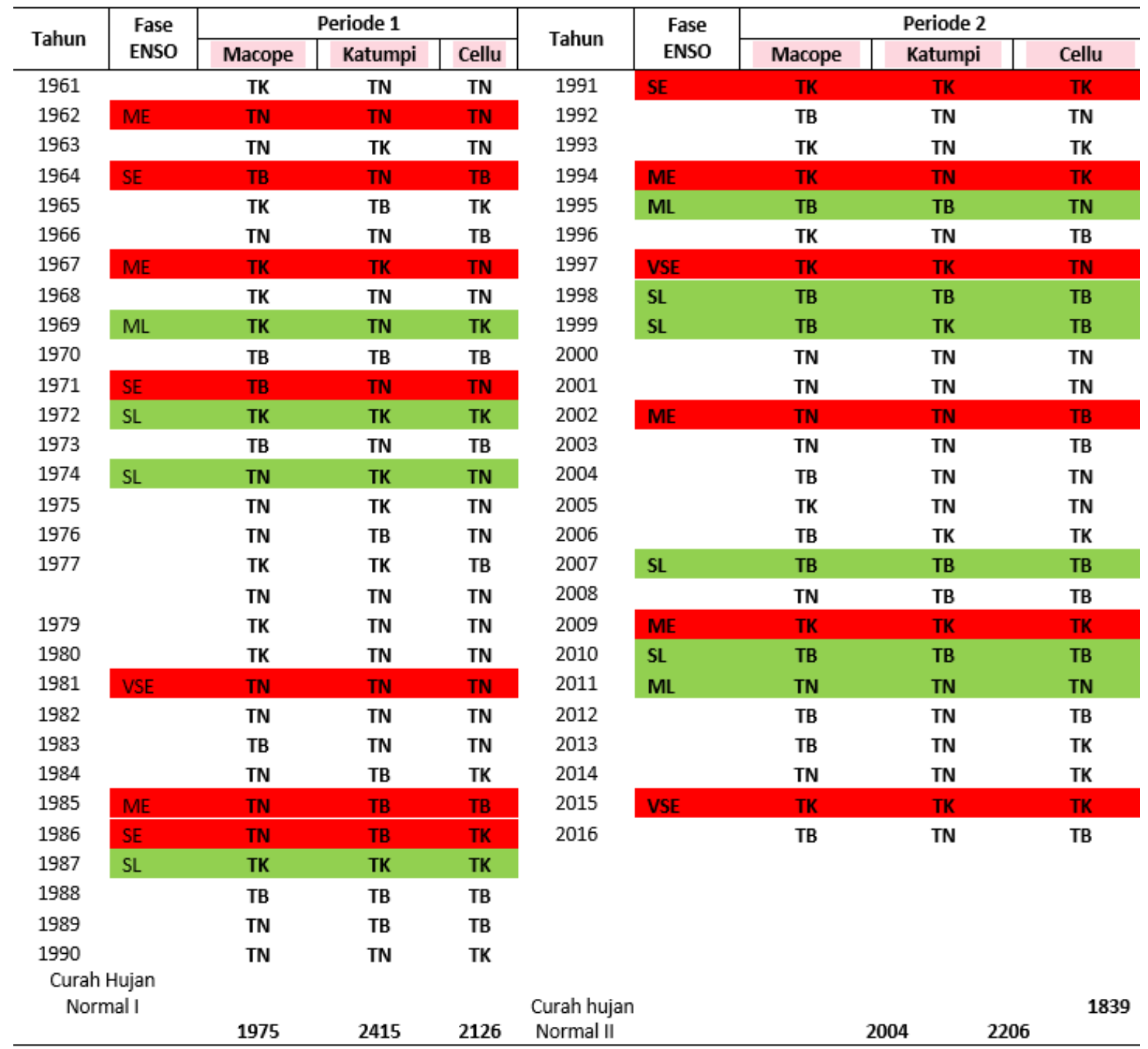



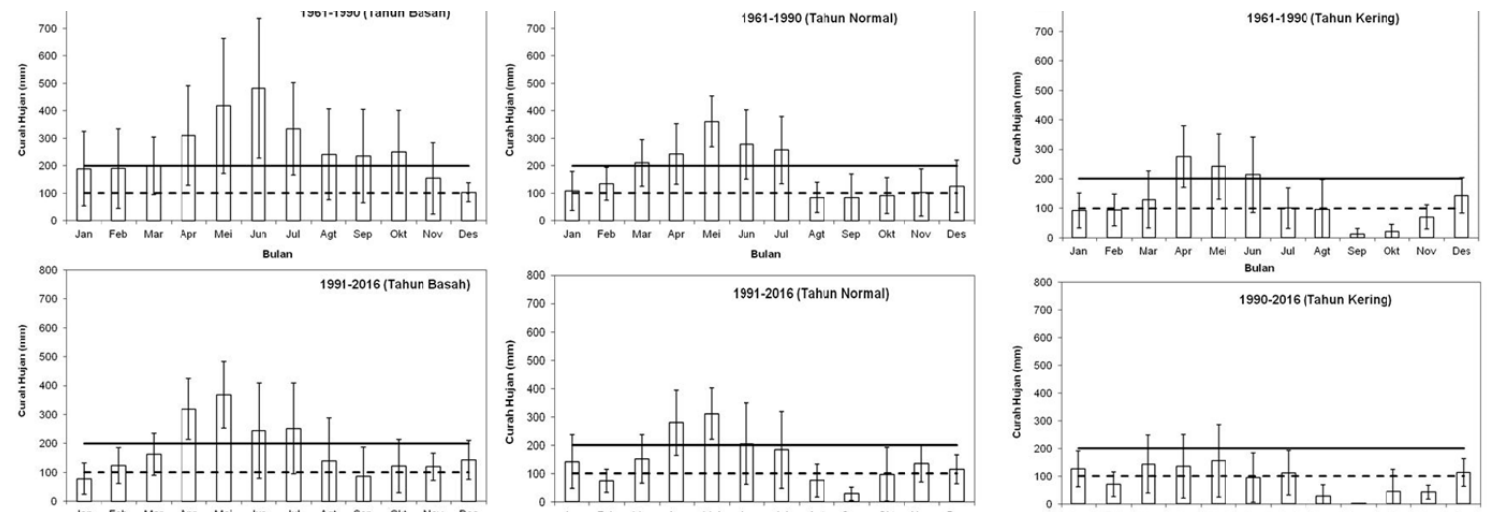

a. Macope
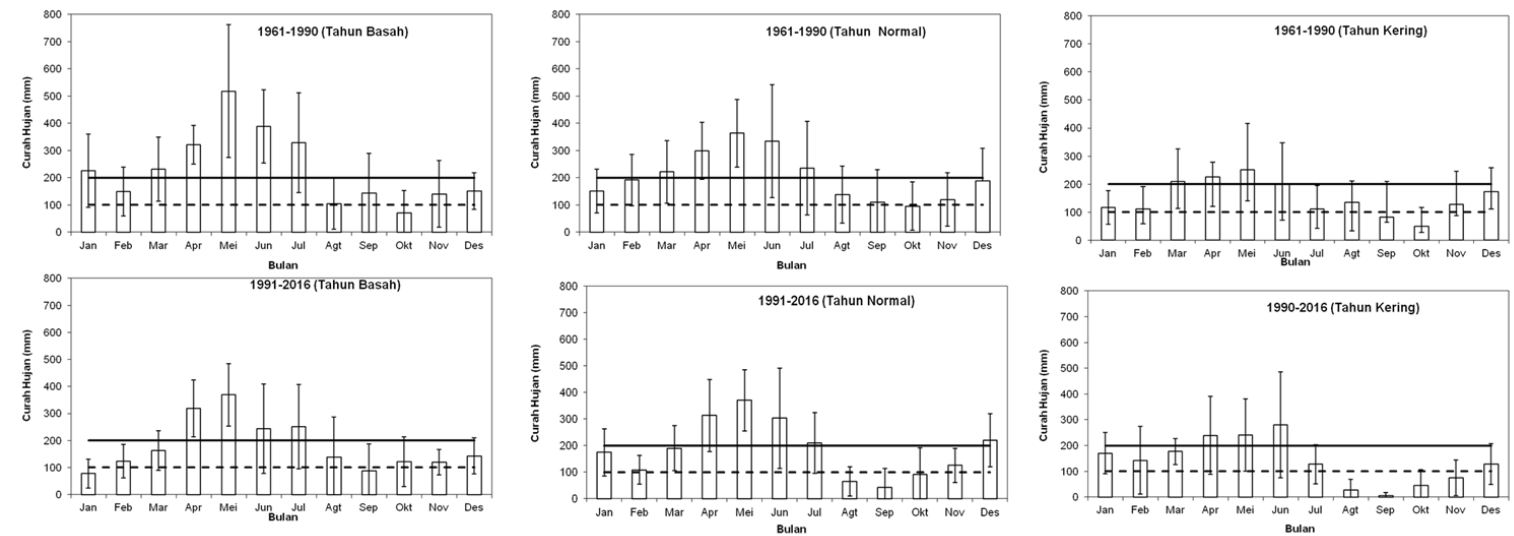

\section{b. Katumpi}
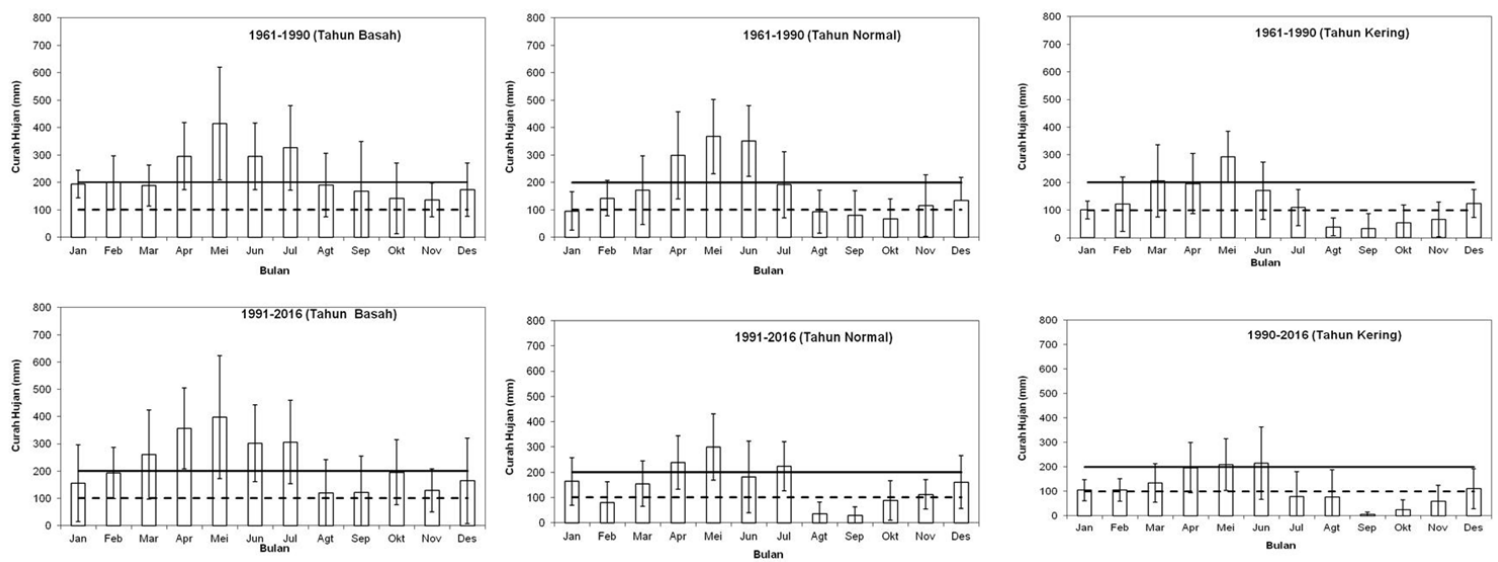

c. Cellu

Gambar 2. Distribusi curah hujan di Tahun Basah, Tahun Normal, dan Tahun Kering 


\section{Periode Masa Tanam}

Periode masa tanam disajikan pada Gambar 2. Curah hujan $200 \mathrm{~mm}$ (garis) dijadikan nilai ambang masa tanam padi sawah sedangkan pada budidaya lahan kering adalah $100 \mathrm{~mm}$ (garis putus-putus).

\section{Periode masa tanam padi sawah}

Terlihat di daerah Macope pada periode I pada TB panjang masa taman adalah tujug bulan yang dimulai pada April s.d. Oktober, pada TN hanya empat bulan, yaitu April s.d. Juli dan pada TK hanya tiga bulan, yaitu April s.d. Juni. Panjang masa tanam di wilayah ini semakin berkurang pada periode II. Ini terlihat bahwa pola curah hujan di wilayah ini berubah dan menyebabkan panjang masa tanam yang semakin singkat dengan pengurangan masa tanamnya sampai tiga bulan.

Perubahan periode masa tanam di wilayah Katumpi hanya terjadi pada TB, sedangkan pada TN dan TK cenderung tetap. Ini mengindikasikan bahwa curah hujan di musim hujan semakin berkurang sedangkan pada musim lain cenderung tetap. Di wilayah Cellu panjang periode tanam cenderung tetap tidak berubah tetapi jika ditelisik lebih dalam terlihat adanya penurunan intensitas curah hujan. Intensitas curah hujan berubah tetapi belum memengaruhi pola hujan dan panjang musim tanam.

Dari ketiga wilayah di kabupaten Bone ini wilayah yang pola curah hujan dan panjang musim tanamnya berubah pada ketiga sifat hujan adalah di Macope, di Katumpi pola curah hujan dan periode musim tanam hanya berubah di TB sedangan di wilayah Cellu Panjang masa tanam cenderung tidak berubah malah pada TB meningkat satu bulan sedangkan pada TN dan TK tidak berubah tetapi intensitas curah hujan terlihat semakin kecil.

\section{Periode masa tanam padi gogo}

Periode masa tanam padi gogo juga mengalami perubahan. Di wilayah Macope, pada periode I pada $\mathrm{TB}, \mathrm{CH}$ sepanjang tahun lebih besar dari $100 \mathrm{~mm}$ yang artinya periode masa tanam padi gogo adalah sepanjang tahun sedangkan pada periode II terjadi pengurangan periode tanam dua bulan. Pada TN terjadi pengurangan potensi periode masa tanam satu bulan dan pada TB periode masa tanam cenderung tetap.

Perubahan periode masa tanam padi gogo di wilayah Katumpi pada TB cenderung tetap, pada TN berkurang tiga bulan dan pada TK berkurang dua bulan. Di wilayah Cellu periode masa tanam padi gogo cenderung tetap pada TB dan TN dan terjadi pengurangan periode masa tanam satu bulan pada TK.

Pengurangan periode masa tanam sampai tiga bulan menimbulkan dampak yang sangat signifikan pada pertanian padi sawah di wilayah ini dimana mengurangi satu siklus tanaman padi. Pola tanam, jenis tanaman, dan waktu tanam harus disesuaikan dengan mengetahui informasi awal musim dan distribusi curah hujan. Peran prakiraan iklim menjadi sangat penting. Di samping itu perlu dipikirkan berbagai teknologi panen air pada musim hujan supaya dapat digunakan pada saat musim kemarau atau mencari sumber air lain baik air permukaan maupun air tanah.

\section{KESIMPULAN}

Pola curah hujan di tiga wilayah di kabupaten Bone selama 55 tahun menunjukkan perubahan dengan perubahan yang bervariasi antar-wilayah kajian. Perubahan pola curah hujan ini telah menyebabkan perubahan periode masa tanam padi sawah dan padi gogo. 
Periode masa tanam padi sawah di Macope pada TB, TN, dan TK berkurang hingga tiga bulan. Periode masa tanam padi gogo di wilayah ini pada TB berkurang dua bulan, pada TN satu bulan, dan pada TK cenderung tetap. Perubahan periode musim tanam padi sawah di Katumpi hanya berubah pada TB dengan pengurangan hingga dua bulan sedangkan periode masa tanam padi gogo berkurang satu bulan pada TN dan TK. Perubahan periode masa tanam juga terjadi di wilayah Cellu dimana terjadi peningkatan periode tanam padi sawah satu bulan pada TB dan pada TK sedangkan pada TN tetap. Periode masa tanam padi gogo di Cellu ini cenderung tetap pada TB dan TN sedangkan pada TK berkurang dua bulan.

Perubahan iklim telah menyebabkan berubahnya pola curah hujan dan berdampak pada periode musim tanam sehingga diperlukan adanya penyesuaian waktu tanam dan pola tanam serta penyesuaian jenis tanaman. Hal lain yang harus diperhatikan adalah perlunya pengembangan teknologi panen air pada musim hujan atau pencarian sumber air lain seperti air tanah agar usaha tani masih dapat berlangsung pada musim kering.

\section{UCAPAN TERIMA KASIH}

Penulis mengucap terima kasih kepada Dr. Yayan Apriyana dan Elza Surmaini atas bimbingan dan saran perbaikannya

\section{DAFTAR PUSTAKA}

Aldrian, Edvin, and R. Dwi Susanto. 2003. "Identification of Three Dominant Rainfall Regions within Indonesia and Their Relationship to Sea Surface Temperature." International Journal of Climatology 23 (12): 1435-52.
As-syakur, A. R. 2009. "The Evaluation of Schmidt-Ferguson Classification on Agroclimat Data at Lombok Island." J.Pijar MIPA III (1): 17-22.

As-syakur, A R, I W Nuarsa, dan I N Sunarta. 2010. "Pemutakhiran Peta Agroklimat Klasifikasi Oldeman Di Pulau Lombok Dengan Aplikasi Sistem Informasi Geografi." Jurnal Agroklimat 2 (3): 79-87.

Biba, M Arsyad. 2012. "Peluang Dan Masalah Pengembangan Jagung Pada Lahan Kering Dengan PTT Jagung Di Sulawesi Selatan." In Prosiding Seminar Nasional Serelia: Teknologi Inovasi Mendukung Swasembada Jagung Dan Diversifikasi Pangan, 628-34. maros: Balai Penelitian Tanaman Serelia.

BMKG. 2017. Prakiraan Musim Hujan 2017/2018 Di Indonesia. Jakarta.

BPS. 2017. Kabupaten Bone Dalam Angka 2017. Bone.

Dalimoenthe, Salwa L., Y Apriana, dan T. June. 2016. "Dampak Perubahan Iklim Terhadap Pola Curah Hujan Dan Defisit Air Di Perkebunan Teh Plantation." Jurnal Peneltian Teh Dan Kina 19 (2): 157-68.

Djufry, Fadjry. 2012. "Pemodelan Neraca Air Tanah Untuk Pendugaan Surplus Dan Defisit Air Untuk Pertumbuhan Tanaman Pangan Di Kabupaten Merauke , Papua." Informatika Pertanian 21 (1): 1-9.

Durre, Imke, Matthew J. Menne, Byron E. Gleason, Tamara G. Houston, and Russell S. Vose. 2010. "Comprehensive Automated Quality Assurance of Daily Surface Observations." Journal of Applied Meteorology and Climatology 49 (8): 1615-33. https:// doi.org/10.1175/2010JAMC2375.1.

Guan, Kaiyu, Benjamin Sultan, Michela Biasutti, Christian Baron, and David B. Lobell. 2015. "What Aspects of Future Rainfall Changes Matter for Crop Yields in West Africa?" Geophysical Research Letters 42 (19): 8001-10. 
Hayashi, Keiichi, Lizzida Llorca, Sri Rustini, Prihasto Setyanto, and Zulkifli Zaini. 2018. "Reducing Vulnerability of Rainfed Agriculture through Seasonal Climate Predictions: A Case Study on the Rainfed Rice Production in Southeast Asia." Agricultural Systems 162 (September 2017): 66-76.

Hendon, Harry H. 2003. "Indonesian Rainfall Variability: Impacts of ENSO and Local Air-Sea Interaction." Journal of Climate 16 (11): 1775-90.

Herniwati, dan Kadir Syafruddin. 2009. "Potensi Iklim, Sumber Daya Lahan Dan Pola Tanam Di Sulawesi Selatan." In Prosiding Seminar Nasional Serelia 2009, 2:978-79. Maros.

Hidayat, Taufan, Yonny Koesmaryono, dan Aris Pramudia. 2006. "Analisis Neraca Air Dalam Penentuan Potensi Musim Tanam Tanaman Pangan Di Provinsi Banten." J. Floratek 2: 55-62.

Jayanti, Kamelia Dwi, Putu Sudira, dan Bambang Hendro Sunarminto. 2016. "Prediksi Neraca Air Untuk Menentukan Masa Tanam Tebu Di Kecamatan Kalasan, Sleman.” Ilmu Pertanian (Agricultural Science) 18 (2): 109.

Laimeheriwa, S. 2014. "Analisis Tren Perubahan Curah Hujan Pada Tiga Wilayah Dengan Pola Hujan Yang Berbeda Di Provinsi Maluku." Jurnal Budidaya Pertanian 10 (2): 71-78.

Latha, A. K. V., Munisamy Gopinath, and A.R.S. Bhat. 2012. "Impact of Climate Change on Rainfed Agriculture in India: A Case Study of Dharma." International Journal of Environmental Science and Development 3 (4): 368-71.

Linderholm, Hans W. 2006. "Growing Season Changes in the Last Century." Agricultural and Forest Meteorology 137 (1-2): 1-14.

Meza, Francisco J., James W Hansen, and Daniel Osgood. 2008. "Economic Value of Seasonal Climate Forecasts for Agriculture: Review of Ex-Ante Assessments and Recommendations for Future Research." Journal of Applied Meteorology and Climatology 47 (5): 1269-86.

Mulyani, Anny. 2016. "Potensi Ketersediaan Lahan Kering Mendukung Perluasan Areal Pertanian Pangan Pendahuluan." In Sumber Daya Lahan Dan Air Prosepek Pengembangan Dan Pengelolaan, edited by Effendi Pasandaran, Rusman Heriawan, and MUhammad Syakir, 12-29. Jakarta.

Musyadik, ., Agussalim, dan Tri Masetyowati. 2014. "Penentuan Masa Tanam Kedelai Berdasarkan Analisis Neraca Air Di Kabupaten Konawe Selatan , Sulawesi Tenggara." $W d y$ ariset 17 (2): 277-82.

Oldeman, L.R. 1975. An Agroclimatic map of Java and Madura, 17.

Puslitbangtan. 2006. "Antisipasi Produksi Pangan Dari Ancaman Kekeringan." Warta Penelitian Dan Pengembangan Pertanian 28 (4): 4-6.

Riajaya, Prima Diarini. 2006. "Sebaran Curah Hujan Sebagai Dasar Penetapan Waktu Tanam Kapas Pada Lahan Sawah Sesudah Padi Di Lamongan, Jawa Timur." Perspektif 5 (1): 26-35.

Riajaya, Prima Diarini, Fitriningdyah Tri Kadarwati, dan Djumali. 2015. "Potensi Sumber Daya Iklim Di Kabupaten Bone Untuk Pengembangan Tanaman Tebu." Buletin Tanaman Tembakau, Serat Dan Minyak Industri 7 (1): 28-44.

Roudier, P., A. Alhassane, C. Baron, S. Louvet, and B. Sultan. 2016. "Assessing the Benefits of Weather and Seasonal Forecasts to Millet Growers in Niger." Agricultural and Forest Meteorology 223: 168-80.

Ruminta, dan T Nurmala. 2016. "Dampak Perubahan Pola Curahan Hujan Terhadap Tanaman Pangan Di Lahan Tadah Hujan Di Jawa Barat.” Agrin 20 (2): 155-68. 
Runtunuwu, E, dan Haris Syahbuddin. 2007. "Perubahan Pola Curah Hujan Dan Dampaknya Terhadap Periode Masa Tanam." Jurnal Tanah Dan Iklim 26: 1-12.

Schmidt, F.H., and J.H.A. Ferguson. 1951. "Rainfall Types Based On Wet And Dry Period Rations For Indonesia With Western New Guinee." Jakarta: Kementerian Perhubungan Djawatan Meteorologi dan Geofisika.

Setiawan, Ogi. 2012. "Analisis Variabilitas Curah Hujan Dan Suhu Di Bali." Jurnal Analisis Kebijakan Kehutanan 9 (1): 66-79.

Surmaini, Elza, dan Haris Syahbuddin. 2016. "Kriteria Awal Musim Tanam: Tinjauan Prediksi Waktu Tanam Padi Di Indonesia." Jurnal Penelitian Dan Pengembangan Pertanian 35 (2): 47.

Susilokarti, Dyah, Sigit Supadmo Arif, Sahid Susanto, dan Lililk Sutiarso. 2017. "Identifikasi Perubahan Iklim Berdasarkan Data Curah Hujan Di Wilayah Selatan Jatiluhur Kabupaten Subang, Jawa Barat." Agritech 35 (1): 98-105.
Taufik, Muh., Maintang, dan M. Basir Nappu. 2015. "Kelayakan Usahatani Jagung Di Sulawesi Selatan.” Jurnal Pengkajian Dan Pengembangan Teknologi Pertanian 18 (1): 67-80.

Thornthwaite, C W. 1948. “An Approach toward a Rational Classification of Climate." Geographical Review 38 (1): 55-94.

Thornthwaite, C W, and J R Mather. 1955. "The Water Balance." Publications in Climatology 8 (1): 1-104.

Timmermann, A., J Oberhuber, M. Esch, M Latif, and E. Roeckner. 2006. "Model Forced By Future Greenhouse Warming." Nature 398: 694-97.

Wredaningrum, Irwanda, dan Sudibyakto. 2014. "Analisis Perubahan Zona Agro-Klimat Di Daerah Istimewa Yogyakarta Ditinjau Dari Klasifikasi Iklim Menurut Oldeman." Jurnal Bumi Indonesia 3 (4): 1-10. 